\title{
NON-AGENDA
}

With the view of causing an increase to take place in the mass of national wealth, or with a view to increase of the means either of subsistence or enjoyment, without some special reason, the general rule is, that nothing ought to be done or attempted by government. The motto, or watchword of government, on these occasions, ought to be - Be quiet... Whatever measures, therefore, cannot be justified as exceptions to that rule, may be considered as non-agenda on the part of government.

\section{Private Sector Lessons for Public Sector Reform in Indonesia}

\section{Ross H. McLeod}

Although the Indonesian economy grew very rapidly — averaging over 7 per cent per annum - during the three decades of the Soeharto era, it suffered a severe setback with the onset of the Asian crisis in 1997-98, and has been unable to achieve similar growth rates on a sustained basis subsequently. The year-on-year growth rate for the March quarter, 2006 was only 4.6 per cent, and this rate has fallen consistently since the end of 2004 (Manning and Roesad, 2006:146). Although most output is generated by the private sector, growth also depends heavily on the provision of complementary inputs by the public sector, most obviously physical infrastructure and an effective legal system. The fact that successive Indonesian governments have performed poorly on both these fronts provides a partial explanation for the relatively low economic growth rates of recent years.

In addition, the private sector is greatly hampered by masses of red tape created by the bureaucracy, as is readily apparent from annual studies undertaken by the World Bank group and published under the general title Doing Business, which are described as 'a series of annual reports investigating the scope and manner of regulations that enhance business activity and those that constrain it' (World Bank, 2004a:viii). According to the latest (2006) report, Indonesia is ranked as low as 115 in a total of 155 countries in the Doing Business database in relation to the 'Ease of Doing Business'.

Ross McLeod is Associate Professor, Indonesia Project, Division of Economics, Research School of Pacific and Asian Studies, The Australian National University. 
In these reports each country's overall Ease of Doing Business ranking is based on its subsidiary rankings on some 10 sub-indices (for details on the Doing Business methodology, see: http://www.doingbusiness.org). Table 1 (based on the 2006 report) presents a selection of the most important of these.

The inadequacies of Indonesia's legal system are reflected in the first two sub-indices, which focus on operations of the judiciary: Enforcement of Contracts, and Closing a Business. In relation to the former, Indonesia scores extremely poorly $-145^{\text {th }}$ among the total 155 countries. Small wonder, then, that private sector entities in Indonesia largely avoid using the courts for contract enforcement - relying instead on other means of protecting their interests, such as the use of private debt collectors, or simply being very careful in their choice of people to do business with. In relation to the latter sub-index, which is basically concerned with the efficacy of bankruptcy procedures, Indonesia ranks $116^{\text {th }}$.

\section{Table 1: Ease of Doing Business in Indonesia: Selected Sub-index Components}

\begin{tabular}{l|l}
\hline & Rank (among 155 countries) \\
\hline Ease of doing business & $\mathbf{1 1 5}$ \\
Matters relying heavily on the courts & 145 \\
Enforcing contracts & 116 \\
Closing a business & \\
Matters involving the bureaucracy & 144 \\
Starting a business & 120 \\
Hiring and firing workers & 118 \\
Paying taxes & 107 \\
Registering property & 107 \\
Obtaining a license & \\
\hline
\end{tabular}

Source: World Bank (2006)

The stultifying impact of the public sector bureaucracy on private sector activity is indicated by the second group of sub-indices. These relate mainly to aspects of private sector business operations that are heavily dependent on the issue of permits, licences, statements, approvals and so on by the bureaucracy (and, to a small extent, by the police). Indonesia ranks as low as $144^{\text {th }}$ in relation to the ease of Starting a Business. Once a business can be established, the weight of bureaucratic regulation of the labour market (Hiring and Firing Workers) pushes Indonesia to $120^{\text {th }}$ place on this aspect, similar to its ranking on the ease of complying with taxation requirements (Paying Taxes). The nation fares little better when it comes to bureaucratic obstacles to Registering Property or Obtaining a Licence, for both of which its ranking is 107. 
The reports do not look at infrastructure deficiencies, but another World Bank (2004b:1, 4) document has this to say:

Indonesia's infrastructure quality ranks among the lowest in the region and is affecting growth, poverty reduction, foreign investment, and the environment... A key impediment is the lack of an overall government strategy for infrastructure and predictable policies in ... critical infrastructure sectors.

\section{The Missing Sector in Sectoral Studies}

Clearly, then, Indonesia's economic progress is greatly hampered by the inadequacies of its public sector. Although the latter is one of the most important sectors of the economy, development economists have done very little to analyse its efficiency and how this might be improved. The focus instead has been on other sectors, such as agriculture, forestry, fishing, manufacturing, mining, telecommunications, transportation, financial services, and so on. Studies of these sectors are often concerned with their efficiency, factors that affect this, and policies that might increase it. Relative neglect of the public sector may reflect the near impossibility of measuring its output, without which there can be no direct measure of efficiency. But the Doing Business reports clearly show that the efficiency of the public sector in Indonesia leaves a great deal to be desired; nobody with any personal experience of its functioning could argue otherwise.

We could draw up an endless list of examples, such as the failure of the taxation and customs authorities to collect anything like the full value of revenues legally due (World Bank, 2003a); the failure of relevant departments and enforcement agencies to prevent illegal logging (Obidzinski, 2005), mining (Erman, 2005) and fishing (Fegan, 2005); the lack of attention to protecting the environment (World Bank, 2003b); the abysmal state of infrastructure (World Bank, 2004b); the poor quality of the state education and health systems (World Bank, 2003a); the fact that individuals and firms see the police and the judiciary more as predators than protectors (World Bank, 2003c); and the seeming inability of the bureaucracy to draft sensible legislation (McLeod, 2006). As the World Bank (2003c:ii) noted:

Corruption levels by any objective standard appear very high, and cause the vast majority of Indonesians themselves to see corruption as an evil that must be eradicated

but while this is receiving considerable attention from the present government, the problem is much wider than corruption. The simple fact is that the public sector is grossly inefficient, which necessarily holds back the performance of the economy as a whole. 


\section{Growth Accounting}

Another strong focus of the development literature in recent years has been 'growth accounting', in which the attempt is made to explain differences in countries' growth rates by looking at factors such as spending on education and health, and the types of policies followed by their governments - particularly in relation to foreign trade, investment and industrialisation. These kinds of studies generate recommendations as to what constitute 'good' policies, but the question as to whether the bureaucracies in question are even interested in 'good' policies - let alone capable of discerning what they are and implementing them - is largely ignored.

This is not particularly helpful. It is logically inconsistent for economists to continue to feed policy recommendations to the Indonesian government when we are confronted on a daily basis with clear evidence that its civil service is highly dysfunctional - which implies that those recommendations are very unlikely to be implemented properly, if at all. For this reason a great deal of the work of economists in the development field in Indonesia seems rather futile. The most pressing priority is to focus on the bureaucracy itself, and to try to find ways to improve its effectiveness. The greater the extent to which this can be achieved, the less the need for outside advice as to what constitutes sound economic policy: a competent civil service can, by definition, design and implement sensible policies and programmes (subject, of course, to political constraints).

Although development economists - at least, those who work on Indonesia - have not devoted much effort to analysing public sector performance, part of the public administration literature does concern itself with efforts to improve the effectiveness of this sector. The so-called 'New Public Management' literature has at its core the main hypothesis that a shift to market orientation in the public sector - applying competition as it is known in the world of profit-oriented business activity - will lead to greater cost-efficiency for governments. The New Public Management concept originated in countries such as the UK and New Zealand (Borins, 2000), and has generated a wave of public sector reforms in many countries since the 1980s, but it seems to have had virtually no impact in Indonesia. As will shortly become apparent, the aim here - in keeping with the New Public Management approach - is to use ideas from private business activity to generate suggestions for civil service reform in Indonesia.

\section{Organisation Performance and Competition}

\section{Progress through emulation}

In all forms of human endeavour some progress is possible through formal training, but probably the main path to advancement is by emulating what others are doing if their performance is clearly superior. The principle is basic commonsense. If my friend can hit the golf ball twice as far as I can, then I should 
try to swing the club more like he does. If one fisherman comes home with a much bigger catch than another, the latter will do well to use similar techniques. If one farmer gets a significantly higher yield from his rice crop, his neighbour would be well advised to copy his methods.

Thus, an obvious point to make is that the Indonesian government could quite easily learn some good ideas about how to improve the performance of its bureaucracy simply by looking at how the civil service operates in any number of other countries; those that rank highly in the Doing Business reports, such as New Zealand, Singapore, the US, Canada, Norway and Australia, would be obvious choices. Indeed, sending bureaucrats and politicians on comparative study tours overseas is a well practised art in Indonesia. Unfortunately, however, most of these study tours have little or no impact, because they are based on the incorrect assumption that civil servants have a strong incentive to increase the effectiveness of their own organisations, lacking only the knowledge of how to do so. On the contrary, most of those who undertake these tours regard them as little more than opportunities to see the world and to supplement their meagre salaries with travel allowances; they are under no illusion that they will be initiating any grand reforms when they return.

\section{Learning from business}

An alternative approach involves making comparisons, not with other countries' bureaucracies, but with other kinds of organisation in quite different fields of activity. In particular, governments can learn a lot about how to improve the performance of their bureaucracies by focusing on the private sector. This idea is anathema to many, perhaps most, Indonesian civil servants, who are accustomed to believing that the economy could hardly function were it not for their wise guidance. My own view on this, supported by the broad findings of the Doing Business reports, is quite the opposite: the civil service (and its associated state enterprise sector) is, by and large, a blight on economic performance. Indonesia's economic progress to date has been in spite of, rather than because of, the bureaucracy.

Why should we imagine that the public sector has anything to learn from the private sector? Nearly all firms have competitors, and if they do not perform as well as these competitors their profits will be low, if not negative. With the passage of time, the more efficient firms will gain larger shares of the market, while others will wither and ultimately die. As poorly performing firms disappear, the resources they would otherwise employ - labour, capital, land and other natural resources - become available for reallocation to more efficient firms and industries, where their now higher productivity will increase the overall size of national income (Ter Wengel and Rodriguez, 2006). In short, the whole process is strongly geared to steady improvement in performance over time.

The keys to high performance here are financial incentives and competition. The financial incentive is the owners' prospect of making large profits by performing well relative to competitors, combined with the risk of losing 
previously accumulated savings (wealth) by performing poorly. The firms that can supply products with superior combinations of price and characteristics desired by their customers will be those that prevail.

The eventual disappearance (through closure or takeover) of relatively poorly managed firms has no counterpart in the public sector. Broadly speaking, national level bureaucracies have no competitors. Thus there is no natural or automatic process that pushes public sector bureaucracies continually to improve their performance. Having made the point that such a process is of crucial importance in the field of business enterprise, it is an obvious next step to infer that its absence helps explain why bureaucracies like those in Indonesia suffer from chronic poor performance, and to suggest that a solution may be found in emulating the practices of successful private sector firms in the area of human resource management.

\section{Building Competitive Teams}

It is axiomatic that the performance of any organisation depends on the performance of the individuals that comprise it. To prosper in a competitive environment, firms need to use people with a range of skills: engineering, scientific, financial, marketing, procurement, administration, personnel management and so on. The decisions made, and the work done, by their employees determine whether the firm succeeds or fails. The job of marketers is to discover what products consumers want; that of engineers to design these and the corresponding production processes; of procurement officers to purchase material and services inputs from reliable, low-cost suppliers; and so on.

Most fundamental of all, the function of human resource management is to ensure that the company recruits sufficient numbers of people with all these kinds of skills, and provides them with strong incentives to perform well. If this function is poorly conceived or managed, the firm is unlikely to survive. In principle, all this is no different from the process of managing the players in a professional football team, where the objective is to put the most effective players in each of the different positions, subject to the price that must be paid to acquire their services.

\section{Competing for places on the team}

Though it is not often discussed or thought of in these terms, the key to the human resource management function is to operate a competition - or, rather, a large number of ongoing competitions for every position within the firm, from the highest to the lowest level. Of course, the number and quality of those who apply for each position will depend upon the remuneration on offer, and the trick here is to seek the optimal trade-off between productivity and cost. Highly productive people will cost more, and it will be worthwhile to recruit somewhat less productive people if the saving in wages or salaries is sufficient to offset their lower productivity. Conversely, although low productivity personnel will be 
relatively cheap to hire, it will be worthwhile to recruit somewhat more productive people if the productivity gain exceeds the extra cost of wages or salaries.

Obviously, firms have no choice other than to offer wages and salaries similar to those offered by other firms; they will have difficulty recruiting workers other than those with low productivity if the wage offered is also low. And they will have difficulty keeping workers on the payroll if their productivity is high enough to get them a job at another, higher paying employer. Of course, payments may be made in kind as well as monetary wages, and firms often find it worthwhile to provide a package of benefits such as transportation, meals, health benefits, housing assistance and so on as part of the overall compensation package, if it is perceived that these benefits will be more highly valued by employees than the cost of providing them. Ultimately, however, individuals are competing for jobs, employers are competing for workers, and the overall price paid is basically determined by the market.

An important additional consideration that makes jobs more or less attractive to employees is the prospect of promotion. If employees are confident they can expect promotion that properly reflects the increasing productivity that accompanies the accumulation of experience and skills (whether by formal or onthe-job training, or learning by doing), they will have a strong incentive to work hard and find ways to increase their productivity. From the firm's point of view, it will be relatively easy to recruit highly motivated and capable personnel if prospects for rapid career advancement appear bright.

In this sense the career trajectory of employees is rather like the evolution of firms: indeed, the employee is exactly analogous to a firm selling services to a customer, the customer in question here being the employer. Employees best able to convince their employer that they have a superior 'product' to sell will be those that obtain the most rapid promotions. Employers that don't want to be disappointed will take care to appraise the performance of current employees, to compare this with that of their peers, and to use these appraisals as important inputs to the promotions process.

\section{Human Resource Management in Indonesia's Civil Service}

As mentioned above, thinking along these lines provides an explanation for why the functioning of Indonesia's civil service leaves so much to be desired, and thus puts us in a position to propose a set of principles to guide civil service reform. The preceding discussion of the process of competition among business enterprises suggests that the poor performance of the Indonesian bureaucracy can be explained by the fact that it has no competitors. It has comparators in the bureaucracies of other countries, of course, but these are not competitors for the privilege of managing the Indonesian economy and polity, and so they are largely ignored. Absence of the need to compete and thus to improve performance continuously has led to significant departures from the fundamental principles of sound human resource management that we see in operation in the profit-oriented world of business. 
First, all parts of the Indonesian bureaucracy have a very rigid organisational structure in which the number of positions at each level in the hierarchy is fixed mechanically by formula, rather than by reference to the volume of work required to be carried out at that level (hence the ubiquitous gross overstaffing at lower levels).

Second, there is very little by way of job classification, except for a few highly specialised professions such as medicine, which means that there is little matching of professional skills and qualifications to the tasks to be carried out (hence the frequent occurrence of a lack of requisite skills at higher levels). It is not widely known that Indonesia had a system of classification or categorisation of positions throughout the civil service until very early in the Soeharto era, when this system was dropped in favour of a military kind of organisational structure in which new recruits were not differentiated other than by the level of education attained (ADB, 2004:58). Yet there is a considerable variety of types of work to be done in the civil service as a whole and within individual ministries, many of which require specific professional skills. It makes no sense to recruit history graduates if what is required is engineers, so it is hardly surprising that many people find themselves undertaking work for which they are not properly trained. This means not only that they will not be able to do their jobs well, but also that their valuable skills will not be fully utilised.

Third, the incentives for good performance on the part of civil servants are very weak, since the current approach ensures that they face no competition from outside: almost the only competition is among (not from) new secondary and tertiary graduates for entry-level positions. Incumbents also face no competition from below, as individuals can only be promoted when positions become vacant because of promotion, relocation, retirement, death or incapacitation of the previous incumbent. Moreover, competition for vacant positions is further limited by obstacles to moving around different parts of the civil service, and by the imposition of seniority (minimum years of service) prerequisites, the effect of which is to reduce the number of individuals eligible to be considered.

Finally, to the extent there is competition for positions, the rules of the game are weak and the playing field is far from level, such that it is common for people to seek promotion not by demonstrating superior performance than their peers but by ingratiating themselves with their superiors and by bribing officials who have the authority to make the appointments in question.

\section{The Process of Organisational Reform}

There is of course no scope for creating competition for the central government bureaucracy: it has a permanent monopoly. (By contrast, with the devolution of many functions of government to regional governments ['decentralisation'] in 2001 the opportunity now exists for provincial, district and municipal governments to compete amongst themselves to attract labour and capital from other parts of the country.) Rather, the key to reform is to recognise that, as with all other organisations, the performance of the civil service depends on the 
performance of the individuals that comprise it - and that this, in turn, depends on the incentives they face and on their capabilities relative to the jobs they are required to do.

It follows that the most promising path to reform involves trying to emulate the human resource management practices of organisations that compete strongly among themselves - in particular, profit-oriented businesses. The key to success is human resource management: putting superior teams of individuals together, and providing them with the appropriate incentives to do well. The way to do this is wholeheartedly to embrace the notion of creating ongoing, fair and vigorous competition for all positions within the civil service.

Once the desirability of encouraging strong competition for civil service positions is accepted, the first concrete step in civil service human resource management reform is to document all the different kinds of jobs that need to be undertaken (as distinct from those that currently exist) in each part of the bureaucracy. For each position, the skill and experience requirements should be described. Next is to determine an appropriate salary for each position, based on research into the private sector labour market directed to discovering the going rates for all relevant combinations of skills and experience.

The end result will be a complete listing of all genuinely needed positions in each department, together with their corresponding salary levels or ranges. This listing would replace the current exceedingly complex and non-transparent system, in which total remuneration has numerous components and depends heavily on characteristics of the individual - including educational qualifications, years of service and number of dependants - as well as the characteristics of the position - most importantly, its level in the hierarchy.

Just as the New Public Management approach emphasises the importance of government procurement of goods and services at lowest cost (for specified quality) through competitive processes, efficiency and attention to the interests of the general public require that the government should not pay more than necessary to attract people with the necessary skills and experience. They also require that the salaries offered are in line with what is being offered by the private sector. In other words, salaries should be differentiated by the type of qualification and by the level of experience, as distinct from the number of years of service and the level in the hierarchy. A person who has served for a long time but at relatively low levels of responsibility should not be paid as much as someone who has served successfully, perhaps for a shorter time, but at a higher level of responsibility.

This requires rethinking what constitutes 'fairness' in salary-setting in the civil service. In the view of the author, the only salary structure that can be called 'fair' is one that matches what is available in the market. Civil service salaries should not have any welfare payment component (that is, they should not include a subsidy by being set above market rates), nor should they try to save money by being set deliberately below market levels. This is false economy: artificially low salaries will attract relatively low productivity people, or they will attract those whose deliberate intention is to engage in corrupt activity in order to achieve at 
least what they could earn outside the civil service. In both cases the saving in salaries is offset by some combination of low productivity and 'leakages'.

In short, it is fair if everybody in the society has the right to offer himself or herself for employment in the civil service. By contrast, it is not fair if people already in the service are protected from competition from outsiders who may be prepared to work harder, who may have taken the trouble to acquire higher qualifications, or who for other reasons may be more capable. By increasing salaries to market levels it will be possible to dispense with the convenient but usually false notion that incumbent civil servants are making big sacrifices and therefore deserve to be protected in their positions. Nobody will be expected to make any sacrifices, so nobody will have any grounds for claiming special treatment.

The next step in civil service human resource management reform is to compare what is needed with what is already available. On the basis of first hand observation of the Indonesian bureaucracy over nearly three decades, the author believes the following will be found:

- a surplus of employees in many positions as a result of a promotions process that treats promotion as a right rather than something to be earned through superior performance, and organisational structures that take no account of the number of people actually needed to do each kind of work within the organisation;

- a relatively large number of individuals who have been promoted into particular positions simply because they have the requisite formal qualifications and a sufficient level of seniority, and yet who are incapable of filling these positions adequately;

- many other individuals who are deserving of promotion to higher positions but who have been held back by lack of seniority or lack of formal qualifications; and

- a lack of needed skills and experience in key areas, especially at the higher levels. ${ }^{1}$

On the basis of this 'stocktake' of human resource requirements and availability, the next phase of the reform process entails:

\footnotetext{
${ }^{1}$ The author recently had the opportunity to observe directly some of these realities when working briefly with an Indonesian government agency whose workload has increased dramatically with the advent of decentralisation. Lack of recruitment to junior levels over many years has left the agency with a severe lack of staff with requisite professional skills at higher levels. But the constraints on recruitment from outside and on rapid promotion from within mean that these positions cannot be filled, implying that the agency itself faces enormous difficulty in expanding its role. At the same time, a visit to the agency's training centre revealed that it had literally scores of administrative support staff, yet only four full-time trainers.
} 
- $\quad$ promoting individuals who appear to be capable of performing well at levels higher than their current positions;

- recruiting individuals from outside to fill human resource gaps if the appropriate people are not available from within; and

- encouraging the departure of individuals who are surplus to requirements, including those previously promoted to levels beyond their capabilities.

Obviously it is no easy matter to rid the organisation of employees who are not needed, or to change a system in which people are accustomed to think of regular promotions as their entitlement, even though both changes are clearly in the interests of the general public. But this is not something that has never been done before. The process of turning around any underperforming organisation typically requires dealing with precisely these kinds of issues. Radical change of this nature usually requires the appointment of a person at the apex of the organisation in question with demonstrated strong management and leadership skills, who is given the responsibility for restructuring, along with the autonomy to push ahead relatively free from outside interference. Again, lessons can be learned from the experience of competitive business enterprises.

Consider the relatively recent restructuring of the then highly unprofitable national airline, Garuda, and the merger of four large and insolvent state-owned banks to form Bank Mandiri. In both cases, the government brought in Robby Djohan, a highly respected CEO from the (private) banking sector, to restructure these very large enterprises (Djohan, no date). Djohan was given near total freedom to do what he felt was necessary to turn these firms around. In both cases he did so successfully by installing his own top management team, selecting the best people within the organisations to fill the remaining positions, and providing generous voluntary retirement packages to other employees no longer needed. He was able eventually to obtain the support of those being let go, not to mention those being rewarded by way of promotion into positions of greater responsibility. These examples show that radical surgery on the workforces of state enterprises - having a great deal in common with the civil service — is politically feasible in the Indonesian context.

Having said that, it should also be noted that both organisations, no longer under Djohan's leadership, have subsequently fallen on hard times, which is a reflection of the desirability of privatisation (the logical, extreme, extension of the New Public Management approach applied to state-owned enterprises). This suggests that further steps need to be taken to ensure that initial gains from reconstituting the workforce in each part of the public sector can be sustained.

\section{Sustaining High Performance}

Beyond the initial restructuring, sustained reform requires implementation of a system that is as competitive as possible: one that is open to competition from below and from outside. Broadly speaking, each position should be contestable by anyone. Current civil servants should be able to apply for different positions 
regardless of their level of seniority; and recruitment from outside should not be restricted only to filling base level positions with new graduates from high schools and tertiary education institutions, but should encompass the recruitment at higher levels of older workers whose experience has been gained in the private sector, in academia, or wherever.

Of fundamental importance here is a set of rules of the game that make the competition fair, combined with mechanisms for enforcing those rules. This is basically about transparency and accountability. Positions should be openly advertised; applications should be properly recorded; selections should be determined by small committees (including at lease one 'outsider') rather than by individuals; the reasons for choosing particular applicants and not others should be documented; and unsuccessful applicants should have the right of appeal to a higher authority. The function of the last in such cases is to review all of the documentation and try to ensure that the only consideration in choosing the successful applicant has been the attempt to get the best available person for the job in question, given the salary on offer.

To the extent that applicants come from outside the civil service it will be necessary for them to demonstrate the adequacy of their qualifications and skills, and to furnish references from past employers. Again, all of this will need to be documented. On the other hand, for individuals seeking promotions or lateral movements within the civil service, records will need to be kept of those individuals' working experience and performance appraisals. Performance appraisals will be required to be undertaken at regular intervals by the individual's superior officer, and the individual should have the right to see these appraisals and to comment on them and contest them, again by appeal to a higher authority. The objective in all this is to ensure that individuals' work is honestly and adequately appraised.

These kinds of systems have been developed in government organisations in other countries and in large business enterprises, from which much can be learned. Presumably there is no such thing as the perfect system, but there can be little doubt that some systems are much closer to perfection than others. The aim should be to emulate systems that appear to function well in other organisations, with due regard for the local context.

\section{Summary}

The key points of the argument presented here in relation to civil service reform in Indonesia are as follows.

First, economic performance overall depends, to a significant extent, on the economic policies designed by governments and bureaucracies in the countries in question. Whether sound policies are chosen, and then designed and implemented properly depends, to a significant extent, on the quality of the civil service. As with all other organisations, the performance of the civil service depends on the performance of the individuals that comprise it, which, in turn, depends on the incentives they face and on their capabilities relative to the jobs they are required 
to do. Performance of individuals can be improved — and indeed maximised — if the guiding principle of personnel management is to encourage strong competition for positions within the civil service, thus emulating the practices of successful business enterprises and of governments in other countries that have embraced New Public Management approaches. A commitment to competition needs to be supported by a clear set of rules governing that competition, and by provisions for enforcement of those rules: the competition must be fair.

Second, the present system of personnel management within Indonesia's civil service departs significantly from these basic principles, which largely explains why its performance is clearly sub-standard. All parts of the bureaucracy have a very rigid organisational structure, in which the number of positions at each level in the hierarchy is fixed by a mechanistic formula, not by reference to the volume of work required to be carried out at that level. There is very little by way of job classification in the civil service except for a few highly specialised professions, which means that there is little matching of professional skills and qualifications to the tasks to be carried out. Civil service incumbents face no competition from outside. The only competition is among new secondary and tertiary graduates for entry-level positions. Civil service officials face no competition from below, since individuals can only be promoted when positions become vacant following the promotion, relocation, retirement, death or incapacitation of the previous incumbent. Competition for vacant positions is limited not only by the ban on recruitment from outside the civil service but also by obstacles to moving around different parts of it, and by the imposition of seniority requirements to limit the number of individuals eligible to be considered. To the extent there is competition for positions, the rules of the game are weak and poorly enforced, such that it is common for people to seek promotions by ingratiating themselves with their superior officers and by bribing officials that have the authority to make the appointments in question.

On the basis of these arguments and observations it is the author's view that the key to reform of Indonesia's civil service, and therefore to maximising the contribution of the public sector to Indonesia's development, is to extend New Public Management approaches regarding the procurement of goods and services to the sphere of human resource management, by encouraging vigorous and fair competition for positions within the civil service.

\section{References}

Asian Development Bank (2004), Country Governance Assessment Report, Republic of Indonesia, Manila, http:// www.adb.org/Documents/Reports/CGA/ino.asp.

Borins, S. (2002), 'New Public Management, North American Style', Ch. 11 in K. McLaughlin, S. Osborne, and E. Ferlie (eds), The New Public Management: Current Trends and Future Prospects, Routledge, London and New York.

Djohan, R. (no date), The Art of Turnaround: Kiat Restrukturisasi, Aksara Karuna, Jakarta. 
Erman, E. (2005). 'Illegal Coalmining in West Sumatra: Access and Actors in the PostSoeharto Era', pp. 206-15 in B. Resosudarmo (ed.), The Politics and Economics of Indonesia's Natural Resources, Institute of Southeast Asian Studies, Singapore.

Fegan, B. (2005), 'Offshore Fishing', Box 10.1 in I. Dutton, 'If Only Fish Could Vote: The Enduring Challenges of Coastal and Marine Resources Management in PostReformasi Indonesia', pp. 162-78 in B. Resosudarmo (ed.), The Politics and Economics of Indonesia's Natural Resources, Institute of Southeast Asian Studies, Singapore.

Manning, C. and K. Roesad (2006), 'Survey of Recent Developments', Bulletin of Indonesian Economic Studies August:143-70.

McLeod, R. (2006), 'Indonesia’s New Deposit Guarantee Law’, Bulletin of Indonesian Economic Studies April:59-78.

Obidzinski, K. (2005), 'Illegal Logging in Indonesia: Myth and Reality’, pp. 193-205 in B. Resosudarmo (ed.), The Politics and Economics of Indonesia's Natural Resources, Institute of Southeast Asian Studies, Singapore.

Ter Wengel, J. and E. Rodriguez (forthcoming, 2006), 'Productivity and Firm Dynamics: Creative Destruction in an Indonesian Panel Data on Manufacturing, 1994-2000', Bulletin of Indonesian Economic Studies December.

World Bank (2003a), CGI Brief: Beyond Macroeconomic Stability, Report No. 27374-IND, World Bank, Washington DC.

World Bank (2003b), Indonesia Environment Monitor 2003, World Bank, Washington DC.

World Bank (2003c), Combating Corruption in Indonesia: Enhancing Accountability for Development, World Bank, Washington DC.

World Bank (2004a), Doing Business in 2004: Understanding Regulation, World Bank and International Finance Corporation, Washington DC.

World Bank (2004b), Averting an Infrastructure Crisis: A Framework for Policy and Action, World Bank, Washington DC.

World Bank (2006), Doing Business in 2006: Creating Jobs, World Bank and International Finance Corporation, Washington DC.

The author gratefully acknowledges helpful comments from two referees, which have led to significant improvements in the paper. 